\title{
PERANAN PROTEIN ADHESI MATRIKS EKSTRASELULAR DALAM PATOGENITAS BAKTERI STAPHYLOCOCCUS AUREUS
}

\author{
Cut Asmaul Husna ${ }^{1}$ \\ ${ }^{1}$ Bagian Mikrobiologi, Prodi Pendidikan Dokter Fakultas Kedokteran Universitas Malikussaleh \\ Corresponding Author : cutasmaulhusnadr@gmail.com
}

\begin{abstract}
Abstrak
Bakteri Staphylococcus merupakan salah satu bakteri yang sering menimbulkan infeksi pada manusia.Beberapa spesiesnya merupakan flora normal pada kulit dan selaput lendir manusia, ada yang bersifat patogen yang dapat menyebabkan infeksi piogenik bahkan septikemia. Staphylococcus aureus merupakan spesies yang paling invasif. Bakteri ini memiliki beragam faktor virulensi, yang mencakup protein-protein permukaan yang berperan dalam perlekatan kuman, enzim-enzim yang menguraikan protein, dan toksin yang merusak sel penjamu. Faktor virulensi S. aureus saling mempengaruhi, dengan struktur dan sekresi produknya yang berperan dalam patogenesis infeksi. Banyak faktor yang berperan dalam patogenitas bakteri Staphylococcus aureus, mulai dari metabolit bakteri, faktor virulensi sampai perananprotein adhesi matriks ekstraseluler.
\end{abstract}

Kata kunci : S. aureus, patogenitas, adhesi

\section{Protein Roles Of Extraselular Mathemic Adhesion In Staphylococcus Aureus Bacteria}

\begin{abstract}
Staphylococcus is one of the bacteria that often causes infections in humans. Some species are normal flora in the skin and mucous membranes of humans, some are pathogenic which can cause pyogenic infections and even septicemia. Staphylococcus aureus is the most invasive species. This bacterium has a variety of virulence factors, which include surface proteins that play a role in the attachment of germs, enzymes that break down proteins, and toxins that damage host cells. The virulence factors of Staphylococcus aureus influence each other, with the structure and secretion of their products which play a role in the pathogenesis of infection. Many factors play a role in the pathogenicity of Staphylococcus aureus bacteria include bacterial metabolites, virulence factors and adhesion proteins ofextracellular matrix.
\end{abstract}

Keywords : S. aureus,pathogenicity, adhesion 


\section{PENDAHULUAN}

Masalah infeksi masih merupakan masalah kesehatan bagi negara maju dan berkembang. Berbagai mikroorganisme dapat menyebabkan infeksi termasuk bakteri, virus, jamur dan protozoa. ${ }^{17}$ Insidensi infeksi apapun meningkat dan menurun seiring dengan perubahan imunitas populasi penjamu dan akibat perubahan virulensi patogen. ${ }^{9}$ Staphylococcus aureus termasuk salah satu jenis bakteri patogen yang sering menimbulkan infeksi dan kelainan pada kulit. ${ }^{23}$ Beberapa spesiesnya merupakan flora normal pada kulit dan selaput lendir manusia, yang lain dapat menyebabkan supurasi bahkan septikemia fatal. ${ }^{3}$ Staphylococcus aureus merupakan spesies yang paling invasif dan paling berbeda dari spesies lainnya karena memiliki enzim koagulase. Organisme ini ditemukan $40 \%$ pada orang sehat, di bagian hidung, kulit, ketiak atau perineum. ${ }^{9}$

Staphylococcus dapat menyebabkan penyakit berkat kemampuannya melakukan pembelahan dan menyebar luas ke dalam jaringan melalui produksi beberapa bahan ekstraseluler. Beberapa bahan tersebut dapat berupa enzim maupun toksin. ${ }^{3}$ Staphylococcus aureus dan Staphylococcus virulen lainnya memiliki beragam faktor virulensi, yang mencakup protein-protein permukaan yang berperan dalam perlekatan kuman, enzim-enzim yang menguraikan protein, dan toksin yang merusak sel penjamu. Staphylococcus dibedakan karena memiliki banyak plasmid, yang mengkode protein-protein yang berperan dalam resistensi antibiotik dan faktor virulensi lainnya. ${ }^{12}$

Struktur S. aureus memiliki protein permukaan yang membantu penempelan bakteri pada sel inang, berupa laminin dan fibronektin yang membentuk matriks ekstraseluler pada permukaan epitel dan endotel. Selain itu, beberapa galur mempunyai ikatan protein fibrin/fibrinogen yang mampu meningkatkan penempelan bakteri pada darah dan jaringan, sebagian besar memiliki protein ikatan terhadap fibronektin dan fibrinogen. Adhesin yang dapat berikatan dengan kolagen, interaksi ini penting untuk penempelan bakteri pada jaringan. $^{23}$

Faktor virulensi $S$. aureus saling mempengaruhi, dengan struktur dan sekresi produknya yang berperan dalam patogenesis infeksi. Staphylococcus aureus memiliki sejumlah protein permukaan dalam menimbulkan infeksi, yang disebut dengan "microbial surface components recognizing adhesive matrix molecules" (MSCRAMMs) yang memperantarai perlekatan ke jaringan penjamu. MSCRAMMs berikatan dengan molekul kolagen, fibronektin dan fibrinogen serta MSCRAMMs lainnya yang berperan sama dalam adhesi ke komponen jaringan penjamu. ${ }^{20}$ 
Adhesi matriks berperan penting dalam fungsi normal sel dan jaringan tubuh. Penemuan dalam mikrobiologi modern menyebutkan bahwa adhesi matriks juga berperan patogen, misalnya bertanggungjawab dalam beberapa tipe keracunan makanan, yang menginfeksi tubuh dengan menggunakan sistem adhesi yang berperan masuk ke dalam sel sehat. ${ }^{1}$

\section{BAKTERI STAPHYLOCOCCUS AUREUS}

Staphylococcus aureus merpakan penyebab utama infeksi yang didapat di komunitas dan penyebab sepsis nosokomial. ${ }^{4,5}$ Manifestasi klinis menyebar luas termasuk bakterimia, endokarditis, pneumonia, osteomielitis, artritis septik, dan pembentukan abses. ${ }^{31}$

Bakteri Staphylococcus merupakan salah satu bakteri yang sering menimbulkan infeksi pada manusia. Staphylococcus termasuk dalam famili micrococcaceae. Bakteri ini berbentuk bulat dan cenderung menyerupai buah anggur. Staphylococcus berukuran $1 \mu \mathrm{m}$ tersusun dalam bentuk kluster tidak teratur, berpasangan dan tidak membentuk spora. Tumbuh cepat pada beberapa media dan dengan aktif melakukan metabolisme, melakukan fermentasi karbohidrat, menghasilkan bermacam pigmen dari warna putih hingga kuning gelap. ${ }^{3}$ Staphylococcus aureus merupakan salah satu spesies Staphylococcus yang dapat menghasilkan pigmen berwarna kuning emas sehingga dinamakan aureus. Bakteri ini dapat tumbuh dengan atau tanpa bantuan oksigen. ${ }^{23}$ Organisme Staphylococcus aureus adalah kokus gram positif yang piogenik, non motil dan berkelompok.Staphylococcus aureus menimbulkan peradangan piogenik yang khas karena sifat destruktif lokalnya, baik lesi terletak di kulit, tulang, atau katup jantung. ${ }^{12}$

\section{METABOLIT BAKTERI}

Bakteri Staphylococcus mengandung polisakarida dan sebagian besar bahan ekstraselular yang bersifat antigenik. Polisakarida yang ditemukan pada jenis yang virulen adalah polisakarida A yang merupakan komponen dinding sel yang dapat larut dalam asam trikloroasetat. Antigen ini merupakan komponen peptidoglikan yang dapat menghambat fagositosis. Bakteriofaga terutama menyerang bagian ini. Antigen protein A berada diluar antigen polisakarida ; kedua antigen ini membentuk dinding sel bakteri. ${ }^{23}$

Peptidoglikan, suatu polimer polisakarida yang mengandung subunit-subunit yang bergabung memberikan eksoskeleton yang kaku dari dinding sel. Peptidoglikan dapat dirusak 
oleh asam kuat atau paparan lisozim. Asam teikoat yang merupakan polimer gliserol atau ribitol fosfat, diikat ke peptidoglikan dan dapat menjadi antigenik. Beberapa galur S. aureus mempunyai kapsul yang mneghambat fagositosis oleh leukosit polimorfonuklear kecuali jika terdapat antibodi spesifik. Sebagian besar galur S. aureus mempunyai koagulase atau faktor penggumpalan pada permukaan dinding sel, ikatan koagulase secara non enzimatik pada fibrinogen menyebabkan agregasi pada bakteri. ${ }^{3}$

Staphylococcus dapat menyebabkan penyakit berkat kemampuannya melakukan pembelahan dan menyebar luas ke dalam jaringan dan melalui produksi beberapa bahan ekstraseluler. Beberapa bahan tersebut adalah enzim, yang lain dapat berupa toksin. Staphylococcus aureus menghasilkan 3 macam metabolit, yaitu metabolitnontoksin, eksotoksin dan enterotoksin. ${ }^{3}$

\section{FAKTOR VIRULENSI}

Staphylococcus aureus mengeluarkan lebih banyak toksin ekstraseluler, hemolisin, enzim dan komponen seluler daripada bakteri lain, semua faktor ini dianggap bertanggung jawab terhadap virulensi. ${ }^{26}$ Staphylococcus aureus dan Staphylococcus virulen lainnya memiliki beragam faktor virulensi, yang mencakup protein-protein permukaan yang berperan dalam perlekatan kuman, enzim-enzim yang menguraikan protein, dan toksin yang merusak sel penjamu.Staphylococcus dibedakan karena memiliki banyak plasmid, yang mengkode protein-protein yang berperan dalam resistensi antibiotik dan faktor virulensi lainnya. ${ }^{12}$

Faktor virulensi $S$. aureus yang lainadalah : ${ }^{23}$

- Beberapa protein invasin membantu invasi dan penyebaran bakteri ke dalam tubuh seperti leukosidin, kinase dan hialuronidase.

- Beberapa faktor permukaan dapat menghambat fagositosis seperti simpai dan protein A

- Zat-zat biokimia lain yang diproduksi untuk meningkatkan pertahanan terhadap fagositosis, seperti karotenoid dan katalase.

- Enzim koagulase dan faktor pembeku (clotting factor) mempengaruhi kerja imunoglobulin tetentu.

- Beberapa eksotoksin dapat merusak jaringan sel inang sehingga dapat memperberat gejala penyakit.

- Beberapa toksin yang berfungsi untuk melisiskan membran sel inang, seperti hemolisin, leukotoksin, leukosidin. 
- Gen resistensi terhadap antimikroba tertentu sehingga bakteri kebal terhadap antimikroba tersebut

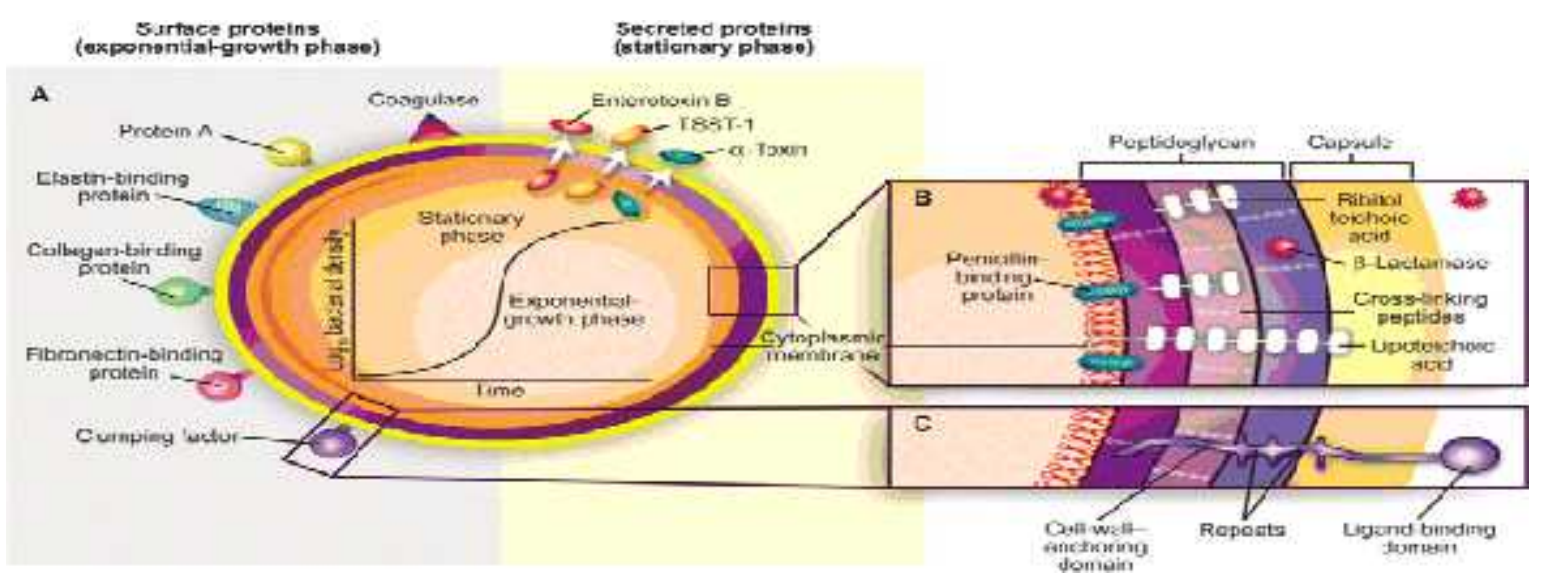

Gambar Faktor patogenitas Staphylococcus aureus, dengan struktur dan sekresi produk, keduanya berperan sebagai faktor virulensi pada TSST. A) Permukaan dan protein sekresi. B and C). Cross-sections dari sel envelope. ${ }^{14}$

\section{IMUNOPATOGENESIS INFEKSI S. AUREUS}

Kemampuan patogenik dari galur S. aureus adalah pengaruh gabungan antara faktor ekstraseluler dan toksin bersama dengan sifat daya sebar invasif. Pada satu sisi semata-mata diakibatkan oleh ingesti enterotoksin, pada sisi yang lain adalah bakterimia dan penyebaran abses pada berbagai organ. Peranan berbagai bahan ekstraseluler pada patogenesis berasal dari sifat masing-masing bahan tersebut. ${ }^{3}$

Staphylococcus aureus memproduksi koagulase yang mengkatalisis perubahan fibrinogen menjadi fibrin dan dapat membantu organisme ini membentuk barisan perlindungan. Bakteri ini juga memiliki reseptor terhadap permukaan sel penjamu dan protein matriks (misalnya fibronektin dan kolagen) yang membantu organisme ini untuk melekat. Bakteri ini mempunyai enzim litik ekstraseluler (misalnya lipase), yang memecah jaringan penjamu dan membantu invasi. S. aureus menimbulkan peradangan piogenik yang khas karena sifat destruktif lokalnya, baik lesi terletak di kulit, tulang, atau katup jantung. ${ }^{12}$ Beberapa strain memproduksi eksotoksin poten, yang menyebabkan sindrom syok toksik. Enterotoksin yang diproduksi juga dapat menyebabkan diare. ${ }^{9}$

Bentuk virulen $S$. aureus yang tahan terhadap fagositosis sebagian disebabkan oleh pembentukan kapsul secara in vivo dan sebagian karena beberapa faktor seperti enzim koagulase yang melindungi bakteri terhadap fibrin. Kemampuan komponen dinding sel seperti protein A untuk bergabung dengan bagian Fc dari IgG bertanggung jawab menghambat fagositosis strain virulen, tetapi kompleks IgG-protein A mengikat komplemen. 
S. aureus dapat mudah difagositosis dengan antibodi yang cukup, namun sebagian besar bakteri tetap bertahan hidup dan sangat sulit untuk dieliminasi seluruhnya. Bila infeksi tidak teratasi dengan baik, lesi berat dapat terjadi pada penjamu yang imun berupa hipersensitifitas lambat tipe $1 \mathrm{~V}^{25}$

Infeksi $S$. aureus dapat terjadi melalui mekanisme sebagai berikut :

- Perlekatan pada protein sel inang

Struktur $S$. aureus memiliki protein permukaan yang membantu penempelan bakteri pada sel inang, berupa laminin dan fibronektin yang membentuk matriks ekstraseluler pada permukaan epitel dan endotel. Selain itu, beberapa galur mempunyai ikatan protein fibrin/fibrinogen yang mampu meningkatkan penempelan bakteri pada darah dan jaringan, sebagian besar memiliki protein ikatan terhadap fibronektin dan fibrinogen. Adhesin yang dapat berikatan dengan kolagen, interaksi ini penting untuk penempelan bakteri pada jaringan. $^{23}$

Staphylococcus aureus mengekspresikan reseptor permukaan untuk fibrinogen (faktor penggumpalan atau clumping factor), fibronektin dan vitronektin, serta menggunakan molekul-molekul ini sebagai jembatan untuk mengikat sel endotel penjamu. Lipase S. aureus menguraikan lemak dipermukaan kulit, dan ekspresinya berkaitan dengan kemampuan bakteri ini dalam menimbulkan abses kulit. Stafilokokus juga memilki protein A dipermukaannya, yang mengikat bagian Fc dari molekul imunoglobulin. ${ }^{12}$

Beberapa bakteri membentuk biofilm polisakarida yang membantu kolonisasi bakteri pada alat prostetik yang dipasang didalam tubuh, seperti kateter. Beberapa strain Staphylococcus memiliki gen yang memperantarai perlekatan ke plastik dan ke molekul biologis yang melapisi alat intravaskular. Berbagai strain $S$. aureus dapat menempel atau terikat ke bermacam-macam molekul penjamu yang mungkin terpajan akibat terjadi kerusakan jaringan seperti fibronektin, vitronektin dan kolagen. ${ }^{9}$

- Invasi

Mikroorganisme memiliki strategi yang berbeda-beda dalam melintasi sawar mukosa atau berbagai jenis membran sel. Saat melewati sawar ini, mikroorganisme tersebut harus mampu bertahan hidup dan bermultiplikasi saat menginvasi penjamu. ${ }^{9}$

Invasi $S$. aureus terhadap jaringan inang melibatkan sejumlah besar kelompok protein ekstraseluler.

○ $\alpha$ Toksin

Toksin yang dapat merusak membran sel/ jaringan inang, merupakan monomer yang berikatan dengan membran sel yang rentan. Jika terikat dengan toksin ini, 
dapat menyebabkan terjadinya serangkaian reaksi sekunder yang dapat menyebabkan pelepasan sitokin, selanjutnya akan mempercepat pembentukan mediator inflamasi. Kejadian ini dapat menyebabkan gejala-gejala renjat septik pada infeksi S.aureus yang berat. ${ }^{23}$ Hemolisin S.aureus terutama hemolisin $\alpha$ adalah suatu protein eksotoksin yang dikode kromosom yang tidak hanya melisiskan sel darah dan menghancurkan sel-sel lain. ${ }^{26}$

○ $\beta$ Toksin

Sfingemielinase yang merusak membran yang kaya kandungan lipid. $\beta$ toksin dapat ditemukan dalam bakteriofaga lisogenik.

○ $\gamma$ Toksin (leukotoksin) dan leukosidin

kompleks protein toksin yang dapat merusak membran sel yang rentan. Leukotoksin bersifat hemolitik, 90\% isolat yang diisolasi dari luka nekrotik kulit menunjukkan adanya leukotoksin. ${ }^{23}$

○ Koagulase

protein ekstraseluler yang dapat berikatan dengan protrombin inang untuk membentuk sebuah kompleks yang disebut stafilotrombin. Koagulase menunjukkan sifat virulensi bakteri S.aureus yang dapat melindungi dirinya dari fagositosis dan menghalangi sistem kerja imun inang. ${ }^{23}$

○ Eksotoksin

Yang dapat merusak jaringan penjamu dan menimbulkan penyakit SEA-G, TSST (Toxine Shock Syndrome Toxic). ${ }^{29}$

- Stafilokinase

Enzim yang diproduksi S.aureus yang berfungsi sebagai aktivator plasminogen sehingga dapat melisiskan fibrin. Enzim ini dapat membantu penyebaran bakteri dalam jaringan inang. ${ }^{29}$

- Enzim ekstraseluler lain

S.aureus memproduksi enzim protease, lipase, deoksiribonuklease (DNAse) dan enzim pemodifikasi asam lemak (fatty acid modifying enzyme, FAME) yang berperan penting dalam pertahanan diri bakteri dan kemungkinan membantu penyediaan nutrisi bagi bakteri. $^{23}$ 


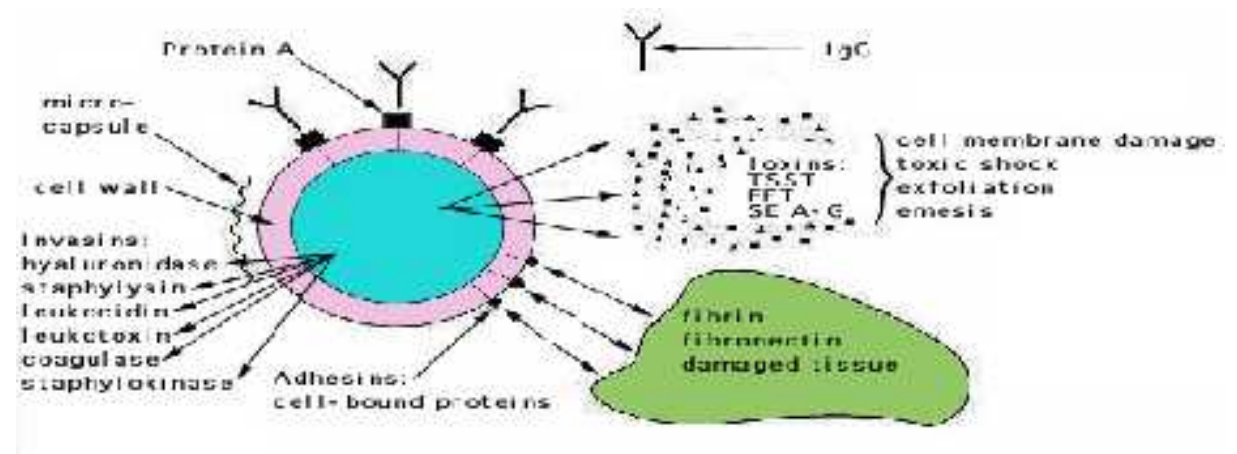

Faktor virulensi yang berperan dalam proses invasi bakteri Staphylococcusaureus. ${ }^{29}$

- Perlawanan terhadap sistem pertahanan inang

Staphylococcusaureus memiliki kemampuan mempertahankan diri terhadap mekanisme pertahanan inang, diantaranya adalah dengan pembentukan simpai polisakarida (mikrokapsul) yang terdapat pada permukaan selnya, yang diduga dapat menghalangi proses fagositosis. Selanjutnya, protein A yang merupakan protein permukaan yang berikatan dengan daerah Fc molekul IgG, sehingga dapat mengganggu opsonisasi dan fagositosis bakteri. Faktor petahanan lain adalah leukosidin, yang secara spesifik menghalangi kerja polimorfonuklear leukosit. ${ }^{23}$

\section{PENGARUH PROTEIN ADHESI MATRIKS EKSTRASELULER TERHADAP PATOGENITASSTAPHYLOCOCCUS AUREUS}

Patogenitas bakteri dapat ditentukan oleh kemampuan bakteri untuk melakukan perlekatan pada permukaan mukosa yang dihubungkan dengan struktur permukaan bakteri dan faktor penjamu (host). Perlekatan bakteri pada permukaan mukosa merupakan faktor paling penting dalam patogenitas bakteri. ${ }^{8,27}$ Faktor virulensi bakteri juga dipengaruhi oleh adanya kapsul. Bakteri yang memiliki kapsul bersifat lebih virulen karena adanya kemampuan kapsul polisakarida dalam mencegah fagositosis atau ingesti oleh sel fagositik host. $^{21}$ Sebagian besar strain Staphylococcus memproduksi microkapsul yang berperan dalam patogenitas bakteri. ${ }^{14}$ Adhesi atau perlekatan S. aureus diperantarai oleh kapsul polisakarida dan oleh protein reseptor pada permukaan sel epitel. Protein permukaan S.aureus berperan dalam proses adhesi terhadap protein host seperti laminin dan fibronektin yang tampak pada permukaan matriks ekstraseluler dari epitel dan endotel. ${ }^{13}$ 
Kemampuan patogenik dari galur S. aureus adalah pengaruh gabungan antara faktor ekstraseluler dan toksin bersama dengan sifat daya sebar invasif. Peranan berbagai bahan ekstraseluler pada patogenesis berasal dari sifat masing-masing bahan tersebut. ${ }^{3}$ Bakteri ini juga memiliki reseptor terhadap permukaan sel penjamu dan protein matriks (misalnya fibronektin dan kolagen) yang membantu organisme ini untuk melekat. Bakteri ini mempunyai enzim litik ekstraseluler (misalnya lipase), yang memecah jaringan penjamu dan membantu invasi. ${ }^{12}$ Beberapa bakteri membentuk biofilm polisakarida yang membantu kolonisasi bakteri pada alat prostetik yang dipasang didalam tubuh, seperti kateter. Beberapa strain Staphylococcus memiliki gen yang memperantarai perlekatan ke plastik dan ke molekul biologis yang melapisi alat intravaskular. Berbagai strain S. aureus dapat menempel atau terikat ke bermacam-macam molekul penjamu yang mungkin terpajan akibat terjadikerusakan jaringan seperti fibronektin, vitronektin dan kolagen. ${ }^{9}$

Hasil penelitian dari Teranishi et al (1998) dikutip dariSuarsana (2002) menunjukkan bahwa protein-A positif dari strain Staphylococcus sp. menyerang sel vero dalam jumlah yang lebih besar dibandingkan dengan strain protein-A negatif. Staphylococcus aureus yang disintesis dalam jumlah kecil pada faktor permukaan berhubungan dengan jaringan tubuh host(misalnya kolagen dan fibrinogen-binding protein) dan faktor proteksi terhadap perlawanan tubuh host. $^{28}$

Staphylococcusaureus juga memperlihatkan jarak terhadap cell-wall-associated proteinsyang melakukan perlekatan terhadap matriks ekstraseluler dan komponen plasma terlarut. ${ }^{7}$ Kaitan antara fibronektin dan ikatan fibrinogen terhadap protein dari $S$. Aureusmenunjukkan kemampuan bakteri dalam pembentukan gumpalan plasma. ${ }^{24}$ Dari pengamatan sebelumnya didapatkan adanya hubungan langsung yang relevan antara mekanisme perlekatan S. aureus pada host, yang berpengaruh terhadap sintesis sel endotel dan penggabungan fibronektin kedalam matriks ekstraseluler, dan disekresikan kedalam medium kultur untuk tumbuh secara in vitro. ${ }^{10}$

Staphylococcus aureus memiliki karakteristik yang mampu membantu bakteri ini dalam menghindari sistem imun penjamu selama proses infeksi. Mekanisme pertahanan ini dilakukan melalui produksi mikrokapsul antifagositik (sebagian besar isolat klinik memproduksi tipe 5 atau 8). ${ }^{6}$ Dalam menimbulkan infeksi, S. aureus memiliki sejumlah protein permukaan yang disebut dengan "microbial surface components recognizing adhesive matrix molecules" (MSCRAMMs) yang memperantarai perlekatan ke jaringan penjamu. 
Microbial surface components recognizing adhesive matrix molecules (MSCRAMMs) berikatan dengan molekul kolagen, fibronektin dan fibrinogen serta MSCRAMMs lainnya yang berperan sama dalam adhesi ke komponen jaringan penjamu. ${ }^{20}$ Komponen protein A dari MSCRAMM berikatan dengan bagian Fc dari imunoglobulin dan dapat mencegah terjadinya opsonisasi. Staphylococcus aureus juga mensekresikan protein penghambat kemotaksis dari Staphylococcus atau protein adherens ekstraseluler, yang dihambat dengan ekstravasasi netrofil dan kemotaksis terhadap bagian yang terinfeksi. ${ }^{6}$

PerlekatanS. aureus untuk dapat hidup pada sel endotelial, dengan cepat diikuti oleh internalisasi, proses yang menerima kehadiran bakteri melalui Fibronectin binding protein (FnBPs). Fibronektin, melalui interaksinya dengan reseptor integrin yang tampak pada endothelium merupakan kandidat molekul ideal dalam menyusun rangkaian proses ini. ${ }^{2}$ Banyak patogen invasif lain menggunakan integrin sebagai reseptor seluler termasukStreptococcus pyogenes yang telah menunjukkan invasi ke sejumlah besar sel epitel melalui interaksi antara fibronektin denganintegrin di permukaan sel epitel. ${ }^{18}$

\section{KESIMPULAN}

Bakteri Staphylococcus dapat menyebabkan penyakit berkat kemampuannya melakukan pembelahan dan menyebar luas ke dalam jaringan melalui produksi beberapa bahan ekstraseluler. Staphylococcus aureus memiliki beragam faktor virulensi, yang mencakup protein-protein permukaan yang berperan dalam perlekatan bakteri, enzim-enzim yang menguraikan protein, dan toksin yang merusak sel penjamu.Struktur S. aureus memiliki protein permukaan yang membantu penempelan bakteri pada sel inang, berupa laminin dan fibronektin yang membentuk matriks ekstraseluler pada permukaan epitel dan endotel. Adhesin yang dapat berikatan dengan kolagen, interaksi ini penting untuk penempelan bakteri pada jaringan. Staphylococcus aureus memiliki sejumlah protein permukaan dalam menimbulkan infeksi, yang disebut dengan "microbial surface components recognizing adhesive matrix molecules" (MSCRAMMs) yang memperantarai perlekatan ke jaringan penjamu. MSCRAMMs berikatan dengan molekul kolagen, fibronektin dan fibrinogen serta MSCRAMMs lainnya yang berperan sama dalam adhesi ke komponen jaringan penjamu. Berbagai strain $S$. aureus dapat menempel atau terikat ke bermacam-macam molekul penjamu yang mungkin terpajan akibat terjadikerusakan jaringan seperti fibronektin, vitronektin dan kolagen. Perlekatan bakteri pada permukaan kulit atau mukosa merupakan faktor penting dalam patogenitas bakteri. 


\section{REFERENSI}

1. Beckers WM, Kleinsmith LJ ,Hardin J.,Gregory Bertoni, Lewis J.. 2006. Cell-Cell Recognition and Adhesion, inBecker's World of the Cell. Eight eds. Pearson's. San Fransisco : Benjamin Cummings, Inc. Pp ; 477-483

2. Berendt, A. R. \& McCormick, C. J. (1997). Use of host adhesionmolecules by infectious agents. InAdhesion Molecules in Healthand Disease, 1st edn, pp. 347士379. Edited by L. C. Paul \& T. B.Issekutz. New York : Marcel Dekker.

3. Brooks, Geo, F., Janet S. Butel, Stephen A. Morse, 2005. Staphylococcus, medical microbiology jawetz, melnick, \& Alderberg's, buku 1. Jakarta : Penerbit Salemba Medika ; 317- 326

4. Communicable Disease Surveillance Centre (1998).Bacteraemia and bacterial meningitis, England and Wales. Commun Dis RepCDR Wkly 9, 254.

5. Emori, T. G. \& Gaynes, R. P. (1993).An overview of nosocomial, infections, including the role of the microbiology laboratory. ClinMicrobiol Rev 6, $428 \pm 442$.

6. Foster TJ, Hook M. 1998. Surface protein adhesins of Staphylococcus aureus. Trends Microbiol ;6:484-8. CrossRefMedlineWeb of Science.

7. Foster, T. J. \& McDevitt, D. (1994).Surface-associated proteins of Staphylococcus aureus: their possible roles in virulence. FEMS Microbiol Lett 118, $199 \pm 206$.

8. Freter, R. and G.W. Jones. 1983. Models for Studying the Role of Bacterial attachment inVirulence and Pathogenesis. Rev. Inf. Dis 5. pp 647-658

9. Gillespie, Stephen and Kathleen Bamford. 2009. Staphylococcus, Patogenesesis Penyakit Infeksi dalam At a Glance Mikrobiologi Medis Dan Infeksi, edisi ketiga. Jakarta : penerbit Erlangga ; 32-33, 12-14, 1.

10. Jaffe, E. A. \& Mosher, D. F. 1978. Synthesis of fibronectin by cultured human endothelial cells. $J$ Exp Med 147, 1779 \pm 1791 .

11. Kleinsmith LJ, Kish VM, 1995. Principles of Cell and Molecular Biology. New York : HarperCollins College Publisher.

12. Kumar, Abbas, Faustro. 2010. Dasar Patologis Penyakit Robins \& Cotrans, edisi 7. Jakarta : Penerbit EGC.

13. Ljungh, A, S. Hjerten and T. Wadström. 1985. High surface hydrophobicity of autoaggregating Staphylococcus aureusstrains isolated from human infections studied with the salt aggregation test. Infect. Immun. 47(2): 522-526.

14. Lowy FD. 1998.Staphylococcus aureus infections. N Engl J Med ;339:52032.CrossRefMedlineWeb of Science.

15. McCormick JK, Yarwood JM, Schlievert PM. Toxic shock syndrome and bacterial superantigens: an update. Annu Rev Microbiol 2001;55:77-104.

CrossRefMedlineWeb of Science.

16. Murray RK, Granner DK, Rodwell VW, 2006. Biokimia Harper. Edisi 27. Alih Bahasa: Brahm U. Pendit. Jakarta: EGC.

17. Nasronuddin, Suharto, dkk, 2007. Penatalaksanaan Infeksi Berat Akibat Bakteri, dalam Penyakit Infeksi di Indonesia, Solusi Kini dan Mendatang. Surabaya : penerbit Airlangga University Press ; 220-221. 
18. Ozeri, V., Rosenshine, I., Mosher, D. F., Fassler, R. \& Hanski, E. 1998. Roles of integrins and Fibronectin in the entry ofStreptococcus pyogenes into cells via protein F1. Mol Microbiol 30, $625 \pm 637$.

19. Pankov R, Yamada KM (October 2002). "Fibronectin at a glance". Journal of Cell Science 115 (Pt 20): 3861-3.

20. Patti JM, Allen BL, McGavin MJ, Hook M. 1994. MSCRAMM-mediated adherence of microorganisms to host tissues. Annu Rev Microbiol ;48:585-617.MedlineWeb of Science

21. Pelczar, M.J. and E.C.S. 2006. Dasar-dasarMikrobiologi. (Translated by Hadioetomo,

R.S) Penerbit Universitas Indonesia Press.Jakarta.

22. Rachel J. Gordon1 and Franklin D. Lowy. 2008. Pathogenesis of MethicillinResistant Staphylococcus aureus Infection in Clinical Infectious Diseases, Oxford Journals, Volume 46, Issue Supplement 5

23. Radji, Maksum. 2011. Bakteri Patogen pada Kulit dan Mata, dalam buku ajar mikrobiologi panduan mahasiswa farmasi dan kedokteran. Jakarta : Penerbit EGC ; 179-189.

24. Raja, R. H., Raucci, G. \& Hook, M. 1990.Peptide analogues to a Fibronectin receptor inhibit attachment of Staphylococcus aureus to Fibronectin-coated surfaces. Infect Immun

25. Roitt IM, 2003. Pengenalan antigen.In : Essential Immunology, $8^{\text {th }}$ eds. Jakarta : Widya Medika ; 93-94.

26. Shulmann, Stanford T., John P. Phair, Herbert M. Sommers.1994. Stafilokokus, Penyakit Stafilokokus dan Sindrom shok toksik dalam buku dasar biologis dan klinis penyakit infeksi, edisi keempat. Yogyakarta : penerbit Gajah Mada University Press ; 550-557.

27. Smith, T.H, 1984. The Biochemical challenge ofmicrobial pathogenicity. J. Appl. Bact. 57:395-404

28. Suarsana, N.I. 2002. Protein A : Peranannya dalam mekanisme infeksi. J. Vet. 20023 (1) : $37-43$

29. Todar, kenneth. 2009. Staphylococcus and staphylococcal Disease. The microbial world htm.

30. Vercellotti, GM, Lussenhop, D, Peterson, PK. Bacterial adherence to fibronectin and endothelial cells: a possible mechanism for bacterial tissue tropism. $J$ Lab Clin Med. 1984;103:34-43.

31. Waldvogel, F. A. 1995. Staphylococcus aureus (including toxic shock syndrome). In Mandell, Douglas and Bennett's Principlesand Practice of Infectious Diseases, 4th edn, vol. 2, pp. 1754 \pm 1777 .Edited by G. L. Mandell, J. E. Bennett \& R. Dolins. New York: Churchill Livingstone. 